S.V. Goncharov, V.L. Gurianova, D.O. Stroy, T.I. Drevytska, S.P. Kaplinskii, E.A. Nastenko, M. Litvinenko, R.V. Terletskiy, M.V. Khaitovych, O.O. Moibenko, V.E. Dosenko

\title{
Genetic predisposition to essential hypertension in children: analysis of 17 single nucleotide polymorphisms
}

\begin{abstract}
Study of 17 single nucleotide polymorphisms has been performed to determine the factors of genetic predisposition to essential hypertension. Polymerase chain reaction (PCR) with subsequent analysis of restriction fragment length, allele specific PCR or real-time PCR was used for genotyping of 17 single nucleotide polymorphisms in 14 genes in 145 children with essential hypertension and 144 healthy persons with following complex multivariate statistical analysis. Two single nucleotide polymorphisms - MMP9 $\left(C^{-1562} \rightarrow T\right)$ and NOS3 $\left(G_{1 u_{298} \rightarrow A s p}\right)$ - rs3918242 and $r s 1799983$ - were shown to represent the main independent effects with the highest predictive potential $(77,1 \%$ as indicated by binary logistic regression and $74,6 \%$ testing accuracy shown by Multifactorial Dimensionality Reduction). MMP9 $\left(C^{-1562} \rightarrow T\right)$ and NOS3 (Glu $298 \rightarrow$ Asp) potentially may be used to create predictive algorithm for determination of predisposition to arterial hypertension in children.

Key words: single nucleotide polymorphism, genetics, hypertension, pediatrics.
\end{abstract}

\section{INTRODUCTION}

Genetic predisposition is a strong and necessary background for effects of environmental factors, the worst combinations of which might lead to onset and progression of multigenic diseases, including essential hypertension $(\mathrm{EH})$. The earlier age of disease onset suspects more primary role of genetic factors in its etiology. The cases of $\mathrm{EH}$ in childhood are rare but there is no doubt regarding the leading role of genetic factors in their onset [29]. Single nucleotide polymorphism (SNP) is considered to be genetic phenomenon that constitutes diathesis (more common determination is susceptibility) to almost all chronic diseases including EH [2].

There are a lot of studies concerning association of several SNPs and EH in adults but less information is available about $\mathrm{EH}$ in children [5, 7 19, 21, 40]. SNPs in genes encoding factors of blood pressure regulation (such as NOS3,
$A C E, A G T, A G T R 1, N P P A, N P R 1, E T 1$, etc) are of the main interest for authors investigating this problem and they have found association of some of them with increased blood pressure in early age. Petrovic D. et al. were the first to publish work concerning this aspect in 2002 [39]. They studied frequencies of I/D polymorphism of ACE gene, the $\mathrm{M}_{235} \rightarrow \mathrm{T}$ polymorphism of the angiotensinogen gene $(A G T)$, and the angiotensin II type 1 receptor $(A G T R 1) \mathrm{A}^{1166} \rightarrow \mathrm{C}$ gene polymorphism in group of 57 children (819 years old) with diagnosed EH compared to group of 57 subjects with normal blood pressure, reported that $A G T \mathrm{M}_{235} \rightarrow \mathrm{T}$ polymorphism can be considered as a risk factor for $\mathrm{EH}$ in childhood. The same team of investigators in 2004 was failed to find association of ScaI NPPA gene polymorphism with the level of blood pressure in the same studied group [58]. Snieder H. et al. in their works $(2002,2004$, and 2006) analyzed SNPs in genes encoding beta2-adrenergic

(C) S.V. Goncharov, V.L. Gurianova, D.O. Stroy, T.I. Drevytska, S.P. Kaplinskii, E.A. Nastenko, M. Litvinenko,

R.V. Terletskiy, M.V. Khaitovych, O.O. Moibenko, V.E. Dosenko 
receptor $A D R B 2\left(\operatorname{Arg}_{16} \rightarrow\right.$ Gly and $\left.\mathrm{Gln}_{27} \rightarrow \mathrm{Glu}\right)$, endothelin-1 EDN1 $\left(\mathrm{T}^{-1370} \rightarrow \mathrm{G},+138 / \mathrm{ex} 1 \mathrm{del} /\right.$ ins, T-37/in2C, and Lys $_{198} \rightarrow$ Asn), angiotensinogen $A G T\left(\mathrm{M}_{235} \rightarrow \mathrm{T}\right)$, and angiotensin II receptor type 1 AGTRl $\left(\mathrm{C}^{-521} \rightarrow \mathrm{T}, \mathrm{L}_{191} \rightarrow \mathrm{L}\right.$ and $\left.\mathrm{A}^{1166} \rightarrow \mathrm{C}\right)$ in Caucasians and Afro-Americans. They have evaluated influence of genotype, sex, race, and socioeconomic state on dynamics of changes of blood pressure and left ventricle mass in 15 years long study [20, 42, 43 ]. Although EH was not diagnosed in people included into the study, authors concluded that almost all analyzed SNPs as well as sexual and racial factors influence on blood pressure. Single genome-wide association study identifies some SNPs and their relationship with the blood pressure in adolescents - Canadian researchers identified 3 loci in following genes that are associated with high blood pressure: PAX5, MRPS22, and FTO [31].

In the current work we have studied the frequencies of SNPs in groups of genes involved into regulation of vascular tone (NOS3, $A G T$, $A C E, A G T R 1, N P P B)$ and also of extracellular $(A 2 M, M M P 2, M M P 9)$ and intracellular (LMP2, LMP7, PSMA6) proteolysis, of hypoxia response $(H I F 1 A)$, metabolism $(P P A R G)$, and DNA repair $(X R C C 1)$ in children with $\mathrm{EH}$ and in people with normal blood pressure. We used the integrative analytical approach aimed to evaluate the role of SNPs as genetic basis of predisposition to $\mathrm{EH}$ and created predictive model for EH. It includes 2 SNPs: $M M P 9\left(\mathrm{C}^{-1562} \rightarrow \mathrm{T}\right)$ and NOS3 7 exon $\left(\mathrm{Glu}_{298} \rightarrow\right.$ Asp $)$, that represent 2 main independent effects with the highest predictive potential.

\section{MATERIAL AND METHODS}

\section{Contingent under the Study: Essential Hyper- tension Group and Control Subjects}

Children with diagnosed $\mathrm{EH}$ ranged in age from 9 to 17 years (145 subjects) were included into the study. Each participant's parents of the study provided written informed consent, and study protocols were approved by the institutional review boards of Bogomoletz Institute of Physiology. All members of 24-hour blood pressure monitoring (BPM) was carried out on 5-7 day of in-patient examination using the pressure monitors «ABPM-04/M» («MEDITECH», Hungary) with humeral cuff. Evaluation of BPM data has been realized by commonly accepted approach [44]. The complete clinical examination of patients was carried out according to the recommendations of the European Society of Hypertension, including estimation of renal function (ultrasonic scanning of kidneys, and urine analyses) to exclude the secondary hypertension [27]. While suspecting in patients the renal etiology of hypertension (propensity to increased diastolic blood pressure, night type of hypertension), we carried out the renal dynamic scintigraphy with ${ }^{99 m}$ Tc-diethylene triamine pentaacetic acid and ${ }^{99 \mathrm{~m}} \mathrm{Tc}-\mathrm{S}$-benzoyl mercaptoacetyltriglycine in scintillation gamma cameras PHO Gamma LFOV ("Searle", Holland). Glomerular filtration rate in examined patients for each kidney was ranged from 38 to $98 \mathrm{~mL} / \mathrm{min}$, average $(\mathrm{X} \pm \mathrm{SD})-54,3 \pm 17,2 \mathrm{~mL} /$ min; standardized - $56-144 \mathrm{~mL} / \mathrm{min}$, average $-105,2 \pm 24,9 \mathrm{~mL} / \mathrm{min}$.

Clinically healthy children (144 subjects) were included in control group, examination of them by anamnesis taking, electrocardiography and blood pressure measurement was carried out to confirm absence of cardiovascular pathology.

\section{Genotyping}

Blood samples were taken under sterile conditions into 2,7 mL manovettes containing EDTA potassium salt as an anticoagulant ("Sarstedt", Germany), or buccal epithelium was taken using buccal brushes with the following freezing of samples and their storage at $-20^{\circ} \mathrm{C}$. DNA for genotyping was extracted from the samples using Isogene kits (Russian Federation) according to manufacturer's protocol. PCR with subsequent analysis of restriction fragment length polymorphism (RFLP) was used to determine the SNPs set forth below: NOS3 promoter $\left(\mathrm{T}^{-786} \rightarrow \mathrm{C}\right)$ by methodic proposed by Ghilardi G. et al. with our modifications 
[12], NOS3 7 exon $\left(\mathrm{Glu}_{298} \rightarrow\right.$ Asp) [15], $A G T$ $\left(\mathrm{Met}_{235} \rightarrow \mathrm{Thr}\right)$ and $A G T R 1\left(\mathrm{~A}^{1166} \rightarrow \mathrm{C}\right)$ [4], $N P P B$ promoter $\left(\mathrm{T}^{-381} \rightarrow \mathrm{C}\right)$ [30], $A 2 M 5^{`}$ splice site of exon 18 [6], $A 2 M\left(\mathrm{Ile}_{1000} \rightarrow \mathrm{Val}\right)$ [55], $M M P 9\left(\mathrm{C}^{-1562} \rightarrow \mathrm{T}\right)[18], L M P 2\left(\mathrm{Arg}_{60} \rightarrow \mathrm{His}\right)$ and LMP7 $\left(\mathrm{Lys}_{49} \rightarrow \mathrm{Gln}\right)[50]$, HIF $1 \alpha$ exon $12\left(\mathrm{C}^{1744} \rightarrow \mathrm{T}\right)$ [38], PPARG $\left(\mathrm{Pro}_{12} \rightarrow \mathrm{Ala}\right)[2]$, $X R C C 1\left(\mathrm{Arg}_{399} \rightarrow \mathrm{Gln}\right)$ [26]. Insertion/deletion polymorphisms of NOS3 intron 4 and $A C E$ intron 16 were determined by Wang X.L. et al. and Evans A.E. et al. correspodingly [11, 51]. To detect $M M P 2 \mathrm{C}^{-1306} \rightarrow \mathrm{T}$ we used the allele-specific PCR [34]. Real-time PCR and Taq-Man Assays was used for allelic discrimination in SNP PSMA6 $\left(\mathrm{C}^{-8} \rightarrow \mathrm{G}\right)$ TaqMan ${ }^{\circledR}$ SNP Assay C_11599359_10 and 7500 Fast Real-time PCR System (Applied Biosystems, Foster City, USA) [48].

\section{Statistical analysis}

Clinical data (table 1) was tested for normally distribution using Shapiro-Wilk test and assumption of equality of variances was analyzed with the help of Levine test using SPSS ver. 17.0. Online Encyclopedia for Genetic Epidemiology studies was used to examine Hardy-Weinberg equilibrium. Odds ratios for every single SNP were calculated using SPSS ver. 17.0.

Complex multifactoreal statistical analysis was performed in 3 steps to access the independent main and interaction effects of the studied SNPs. In the $1^{\text {st }}$ step we used a random forest algorithm [46]. Random forests can accommodate thousands of independent variables and have been demonstrated to be among the most accurate statistical learning machines, and are capable of generating useful scaling of importance among predictors. Analyses were performed using the Random Forest as given in the R library.

To find out OR (odds ratios) associated with each predictor, to detect main effects of the most important SNPs chosen by random forest and to reveal what genotypes are associated with an increased risk of essential hypertension, we used a binary logistic regression (performed in SPSS ver. 17.0) in the $2^{\text {nd }}$ step of statistical analysis.

Finally, in the $3^{\mathrm{d}}$ step, we used a non-parametric approach such as Multifactorial Dimensionality Reduction (MDR) software (version 2.0) to detect the interaction effects of the studied SNPs and find out the best model with the highest predicting potential. MDR is a data reduction method that seeks the possibility to identify combinations of multilocus genotypes that are associated with either high risk or low risk of disease. We selected the best MDR model as the one with the maximum testing accuracy. A testing accuracy of 0,5 is expected under the null hypothesis. Statistical significance was determined using 1000-fold permutation tests. The MDR results were considered statistically significant at the $\mathrm{P}<0,05$ level.

\section{RESULTS}

Hardy-Weinberg and chi-square analysis. Data on frequencies of studied SNPs for the group of controls vs. children with EH are summarized in table 2. Frequency distribution of genotypes of all analyzed SNPs were in Hardy-Weinberg equilibrium.

Table 1. Basic characteristics of the individuals involved in the study

\begin{tabular}{|c|c|c|}
\hline Parameter & $\begin{array}{l}\text { Control } \\
(n=144)\end{array}$ & $\begin{array}{c}E H \\
(n=145)\end{array}$ \\
\hline Sex, male/female & $97 / 47$ & $103 / 42$ \\
\hline Age, years $\pm \mathrm{SD}$ & $13.7 \pm 1.12$ & $14.3 \pm 1.62$ \\
\hline $\mathrm{BMI}, \mathrm{kg} / \mathrm{m}^{2} \pm \mathrm{SD}$ & $19.3 \pm 3.44$ & $23.0 \pm 4.26$ \\
\hline $\mathrm{SBP}, \mathrm{mm} \mathrm{Hg} \pm \mathrm{SD}$ & $107.5 \pm 6.86$ & $128.8 \pm 7.94 *$ \\
\hline $\mathrm{DBP}, \mathrm{mm} \mathrm{Hg} \pm \mathrm{SD}$ & $68.4 \pm 6.13$ & $74.8 \pm 8.82$ \\
\hline
\end{tabular}

BMI - body mass index, SBP - systolic blood pressure, DBP - diastolic blood pressure, SD - standard deviation. * $-\mathrm{P}<0.05$ 
Chi-square test. Distribution of genotypes of studied SNPs in children with EH and healthy people (odds ratios with $95 \%$ confidence intervals) is summarized in table 3 .

Random forest analysis. Importance index of 14 analyzed SNPs is summarized in figure 1. It can clearly show that $M M P 9$ is the most important predictor followed by NOS3 7 exon $\left(\mathrm{Glu}_{298} \rightarrow\right.$ Asp) SNP and then NOS3 promoter $\left(\mathrm{T}^{-786} \rightarrow \mathrm{C}\right)$ and $A G T R 1\left(\mathrm{~A}^{1166} \rightarrow \mathrm{C}\right)$. The result of the application of the method suggested by Strobl et al. regarding the reduction of the unimportant predictors is shown in figure 1 (SNPs located to the left of the vertical dashed line). The prediction accuracy for the OOB was $73 \%$.

After selecting the most important predictors we wanted to compare the OOB error rate if only these 4 SNPs are included in the model. Random forest model was built again with 1000 trees and
2 random variables available at each node split. The OOB prediction accuracy did not change at all $(73 \%)$.

Logistic regression analysis. To detect the main effects of 4 most important SNPs selected by random forest and to reveal the genotypes associated with an increased/decreased risk of $\mathrm{EH}$, we used a binary logistic regression ("block enter" method) but only with the 4 SNPs selected by random forest. The prediction accuracy of logistic regression with 4 predictors was $79.5 \%$ and coefficients of logistic regression along with odds ratios, confidence intervals are shown in table 4 . The obtained results suggest that only MMP9 $\left(\mathrm{C}^{-1562} \rightarrow \mathrm{T}\right)$ and NOS3 7 exon $\left(\mathrm{Glu}_{298} \rightarrow\right.$ Asp) are significantly associated with EH while NOS3 promoter $\left(\mathrm{T}^{-786} \rightarrow \mathrm{C}\right)$ and AGTR1 $\left(\mathrm{A}^{1166} \rightarrow \mathrm{C}\right)$ did not reach statistical significance. Genotype $\mathrm{C} / \mathrm{T}\left(\operatorname{MMP} 9\left(\mathrm{C}^{-1562} \rightarrow \mathrm{T}\right)\right)$

Table 2. Percentage distribution of genotypes of studied SNPs in children with essential hypertention and healthy people

\begin{tabular}{|c|c|c|c|c|c|c|}
\hline \multirow{3}{*}{$\begin{array}{c}\text { GENES (POLYMORPHISMS), } \\
\text { REFERENCE SNP ID }\end{array}$} & \multicolumn{6}{|c|}{ GENOTYPES } \\
\hline & \multicolumn{2}{|c|}{ AA } & \multicolumn{2}{|c|}{$\mathrm{Aa}$} & \multicolumn{2}{|c|}{ aa } \\
\hline & Control & EAH & Control & EAH & Control & EAH \\
\hline NOS3 $\left(\mathrm{T}^{-786} \rightarrow \mathrm{C}\right), \mathrm{rs} 2070744$ & 40,7 & 44,4 & 53,2 & 40,7 & 6,1 & 14,9 \\
\hline$N O S 3\left(\mathrm{Glu}_{298} \rightarrow \mathrm{Asp}\right), \mathrm{rs} 1799983$ & 31,1 & 44,7 & 64,5 & 41,3 & 4,4 & 14 \\
\hline $\operatorname{NOS} 3(4 \mathrm{a} / 4 \mathrm{~b})$ & 62,9 & 68,6 & 32,8 & 24,1 & 4,3 & 7,3 \\
\hline$A C E(\mathrm{I} / \mathrm{D})$ & 27,6 & 18,8 & 51,7 & 58 & 20,7 & 23,2 \\
\hline$A G T\left(\mathrm{Met}_{235} \rightarrow \mathrm{Thr}\right), \mathrm{rs} 699$ & 19,8 & 27,4 & 57,5 & 49 & 22,7 & 23,6 \\
\hline $\operatorname{AGTR1}\left(\mathrm{A}^{1166} \rightarrow \mathrm{C}\right), \operatorname{rs} 5186$ & 53,1 & 52,3 & 39,9 & 37,4 & 7 & 10,3 \\
\hline$N P P B\left(\mathrm{~T}^{-381} \rightarrow \mathrm{C}\right), \mathrm{rs} 198388$ & 48 & 34,8 & 33,7 & 46,7 & 18,3 & 18,5 \\
\hline$A 2 M\left(\mathrm{Ile}_{1000} \rightarrow \mathrm{Val}\right), \mathrm{rs} 669$ & 43,8 & 35,5 & 44,5 & 51 & 11,7 & 13,5 \\
\hline$A 2 M(\mathrm{I} / \mathrm{D}), \mathrm{rs} 3832852$ & 47 & 78,8 & 43,3 & 19,7 & 9,7 & 1,5 \\
\hline$M M P 2\left(\mathrm{C}^{-1306} \rightarrow \mathrm{T}\right), \mathrm{rs} 243865$ & 49 & 50 & 45 & 46,1 & 6 & 3,9 \\
\hline$M M P 9\left(\mathrm{C}^{-1562} \rightarrow \mathrm{T}\right), \mathrm{rs} 3918242$ & 64 & 73,8 & 34,9 & 22,6 & 1,1 & 3,6 \\
\hline$L M P 2\left(\operatorname{Arg}_{60} \rightarrow\right.$ His $)$, rs 17587 & 63,7 & 42,2 & 28,7 & 45,7 & 7,6 & 12,1 \\
\hline$L M P 7\left(\mathrm{Lys}_{49} \rightarrow \mathrm{Gln}\right), \mathrm{rs} 2071543$ & 97,5 & 92,5 & 2,5 & 7,5 & 0 & 0 \\
\hline PSMA6 $\left(\mathrm{C}^{-8} \rightarrow \mathrm{G}\right), \mathrm{rs} 1048990$ & 72 & 76,5 & 28 & 21 & 0 & 2,5 \\
\hline HIF $1 A\left(\mathrm{C}^{1744} \rightarrow \mathrm{T}\right), \mathrm{rs} 11549465$ & 80 & 86,3 & 20 & 13 & 0 & 0,7 \\
\hline PPARG $\left(\right.$ Pro $_{12} \rightarrow$ Ala $)$, rs 3856806 & 64,9 & 60 & 31,1 & 38,6 & 4 & 1,4 \\
\hline$X R C C 1\left(\operatorname{Arg}_{399} \rightarrow \mathrm{Gln}\right)$, rs 25487 & 36,2 & 44 & 48,3 & 42,1 & 15,5 & 13,9 \\
\hline
\end{tabular}


Table 3. Distribution of genotypes of studied SNPs in children with essential hypertention and healthy people. Odds ratios with $95 \%$ confidence intervals.

\begin{tabular}{|c|c|c|}
\hline Polymorphism & Genotype & Odds Ratio and $95 \%$ CI \\
\hline \multirow{4}{*}{$\operatorname{NOS} 3\left(\mathrm{~T}^{-768} \rightarrow \mathrm{C}\right)$} & AA & $1($ ref $)$ \\
\hline & $\mathrm{Aa}$ & $1.464(0.854-2.521)$ \\
\hline & aa & $0.472(0.170-1.230)$ \\
\hline & AA & $1(\mathrm{ref})$ \\
\hline \multirow{3}{*}{$\operatorname{NOS3}\left(\mathrm{Glu}_{298} \rightarrow \mathrm{Asp}\right)$} & $\mathrm{Aa}$ & $2.184(1.215-3.927)$ \\
\hline & aa & $0.457(0.149-1.576)$ \\
\hline & AA & $1($ ref $)$ \\
\hline \multirow[t]{3}{*}{$N O S 3(4 \mathrm{a} / 4 \mathrm{~b})$} & $\mathrm{Aa}$ & $1.494(0.715-3.121)$ \\
\hline & aa & $0.712(0.178-2.790)$ \\
\hline & AA & $1($ ref $)$ \\
\hline \multirow[t]{3}{*}{$A C E(\mathrm{I} / \mathrm{D})$} & $\mathrm{Aa}$ & $0.611(0.311-1.216)$ \\
\hline & aa & $0.612(0.265-1.433)$ \\
\hline & AA & $1(\mathrm{ref})$ \\
\hline \multirow{3}{*}{$A G T\left(\mathrm{M}_{235} \rightarrow \mathrm{T}\right)$} & $\mathrm{Aa}$ & $1.586(0.745-3.151)$ \\
\hline & aa & $1.490(0.559-3.433)$ \\
\hline & AA & $1($ ref $)$ \\
\hline \multirow[t]{3}{*}{$A G T 1\left(\mathrm{~A}^{1166} \rightarrow \mathrm{C}\right)$} & $\mathrm{Aa}$ & $1.012(0.567-1.888)$ \\
\hline & aa & $0.732(0.244-2.180)$ \\
\hline & AA & $1($ ref $)$ \\
\hline \multirow[t]{3}{*}{$N P P B\left(\mathrm{~T}^{-381} \rightarrow \mathrm{C}\right)$} & $\mathrm{Aa}$ & $0.519(0.301-0.877)$ \\
\hline & aa & $0.683(0.351-1.431)$ \\
\hline & AA & $1($ ref $)$ \\
\hline \multirow{3}{*}{$A 2 M\left(\mathrm{Ile}_{1000} \rightarrow \mathrm{Val}\right)$} & $\mathrm{Aa}$ & $0.699(0.397-1.229)$ \\
\hline & aa & $0.732(0.344-1.689)$ \\
\hline & AA & $1($ ref $)$ \\
\hline \multirow[t]{3}{*}{$A 2 M(\mathrm{I} / \mathrm{D})$} & $\mathrm{Aa}$ & $3.61(1.966-6.585)$ \\
\hline & aа & $7.801(1.703-35.91)$ \\
\hline & AA & $1($ ref $)$ \\
\hline \multirow[t]{3}{*}{$M M P 2\left(\mathrm{C}^{-1306} \rightarrow \mathrm{T}\right)$} & $\mathrm{Aa}$ & $1.009(0.565-1.890)$ \\
\hline & aa & $1.452(0.369-5.709)$ \\
\hline & AA & $1($ ref $)$ \\
\hline \multirow[t]{3}{*}{$M M P 9\left(\mathrm{C}^{-1562} \rightarrow \mathrm{T}\right)$} & Aa & $1.793(1.019-3.157)$ \\
\hline & aa & $0.346(0.041-2.722)$ \\
\hline & AA & $1($ ref $)$ \\
\hline \multirow[t]{3}{*}{ LMP2 $\left(\operatorname{Arg}_{60} \rightarrow\right.$ His $)$} & $\mathrm{Aa}$ & $0.461(0.259-0.679)$ \\
\hline & aa & $0.443(0.138-1.008)$ \\
\hline & AA & $1(\mathrm{ref})$ \\
\hline \multirow[t]{3}{*}{$L M P 7\left(\right.$ Lys $\left._{49} \rightarrow \mathrm{Gln}\right)$} & $\mathrm{Aa}$ & $0.343(0.07-1.679)$ \\
\hline & aa & NA \\
\hline & AA & $1($ ref $)$ \\
\hline \multirow[t]{3}{*}{ PSMA6 $\left(\mathrm{C}^{-8} \rightarrow \mathrm{G}\right)$} & Aa & $1.440(0.874-2.373)$ \\
\hline & aa & $0.199(0.210-1.751)$ \\
\hline & AA & 1 (ref) \\
\hline \multirow[t]{3}{*}{$\operatorname{HIF} 1 A\left(\mathrm{C}^{1744} \rightarrow \mathrm{T}\right)$} & Aa & $1.540(0.715-3.340)$ \\
\hline & aa & NA \\
\hline & AA & $1($ ref $)$ \\
\hline \multirow{3}{*}{$\operatorname{PPARG}\left(\mathrm{Pro}_{12} \rightarrow \mathrm{Ala}\right)$} & $\mathrm{Aa}$ & $0.749(0.430-1.307)$ \\
\hline & aa & $2.401(0.401-12.989)$ \\
\hline & AA & $1($ ref $)$ \\
\hline \multirow{2}{*}{$X R C C 1\left(\operatorname{Arg}_{399} \rightarrow \mathrm{Gln}\right)$} & $\mathrm{Aa}$ & $1.411(0.719-2.757)$ \\
\hline & aa & $1.408(0.601-4.015)$ \\
\hline
\end{tabular}




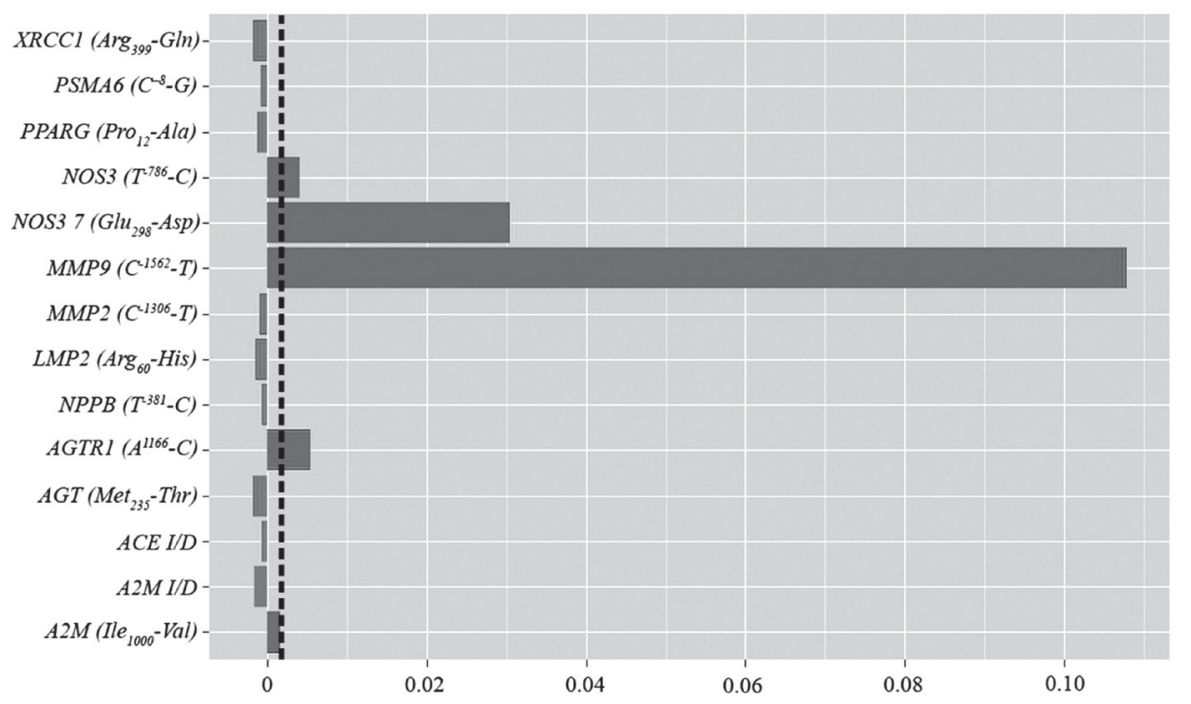

Fig. 1. Variable importance graph of $14 \mathrm{SNPs}$ indicates that $4 \mathrm{SNPs}\left(M M P 9\left(\mathrm{C}^{-1562} \rightarrow \mathrm{T}\right), \operatorname{NOS3}\right.$ promoter $\left(\mathrm{T}^{-786} \rightarrow \mathrm{C}\right)$, NOS3 7 exon $\left(\mathrm{Glu}_{298} \rightarrow \mathrm{Asp}\right)$, AGTRI $\left(\mathrm{A}^{1166} \rightarrow \mathrm{C}\right)$ ) achieved maximum importance score by crossing the vertical dashed line

is associated with the 7,6-fold increased risk of $\mathrm{EH}(\mathrm{OR}=7,579 ; 95 \% \mathrm{CI}-2,390-$ 24,033) while genotype Glu/Asp (NOS3 7 exon $\left.\left(\mathrm{Glu}_{298} \rightarrow \mathrm{Asp}\right)\right)$ is associated with 5.5 fold decreased risk of $\mathrm{EH}(\mathrm{OR}=0,182 ; 95 \%$ CI $-0,052-0,643)$. So we decided to build another model with only these 2 predictors and compare the results. The prediction accuracy of logistic regression with 2 predictors was $77,1 \%$ and coefficients of logistic regression along with odds ratios, confidence intervals are shown in table 5. By removing 2 insignificant SNPs the prediction accuracy of the model decreased only by $2 \%$ so we consider this loss as insignificant and conclude that the most important predictors are $\left(M M P 9\left(\mathrm{C}^{-1562} \rightarrow \mathrm{T}\right)\right.$

Table 4. Results of logistic regression with 4 SNPs in the mode

\begin{tabular}{|c|c|c|c|c|c|c|c|}
\hline SNP & Geno-type & $\begin{array}{l}\text { Coefficient of } \\
\text { regression }\end{array}$ & $\begin{array}{l}\text { Wald sta- } \\
\text { tistics }\end{array}$ & $\begin{array}{c}\mathrm{P} \\
\text {-value }\end{array}$ & OR & $\begin{array}{l}95 \% \mathrm{CI} \\
\text { for OR } \\
\text { lower }\end{array}$ & $\begin{array}{l}95 \% \mathrm{CI} \\
\text { for OR } \\
\text { upper } \\
\end{array}$ \\
\hline \multirow{2}{*}{$\begin{array}{l}M M P 9 \\
\left(\mathrm{C}^{-1562} \rightarrow \mathrm{T}\right)\end{array}$} & $C / T$ & 2,010 & 11,536 & ,001 & 7,47 & 2,34 & 23,82 \\
\hline & $T / T$ & 21,668 & $6,06 \times 10^{-7}$ & 999 & $2,57 \times 10^{9}$ & & \\
\hline \multirow{2}{*}{$\begin{array}{l}\text { NOS3 promoter } \\
\left(\mathrm{T}^{-786} \rightarrow \mathrm{C}\right)\end{array}$} & $T / C$ &,- 3454 & ,316 &, 574 & ,708 &, 21 & 2,36 \\
\hline & $\mathrm{C} / \mathrm{C}$ & 1,795 & 3,324 &, 068 & 6,02 &, 87 & 41,42 \\
\hline \multirow{2}{*}{$\begin{array}{l}\text { NOS3 } 7 \text { exon } \\
\left(\mathrm{Glu}_{298} \rightarrow \mathrm{Asp}\right)\end{array}$} & Glu/Asp & $-1,595$ & 6,092 &, 014 & ,203 &, 057 &, 72 \\
\hline & $A s p / A s p$ & $-2,01$ & 1,633 & ,201 & , 134 & ,006 & 2,92 \\
\hline \multirow{2}{*}{$\begin{array}{l}A G T R 1 \\
\left(\mathrm{~A}^{1166} \rightarrow \mathrm{C}\right)\end{array}$} & $A / C$ & ,925 & 2,339 &, 126 & 2,52 &, 77 & 8,25 \\
\hline & $C / C$ &, 506 & , 179 & ,673 & 1,66 &, 16 & 17,35 \\
\hline \multicolumn{2}{|c|}{ Constant } &, 125 &, 037 & ,848 & 1,133 & & \\
\hline
\end{tabular}

OR - odds ratio, $\mathrm{CI}$ - confidential interval 
and NOS3 7 exon $\left(\mathrm{Glu}_{298} \rightarrow\right.$ Asp) as suggested by logistic regression.

Multifactorial dimensionality reduction approach. To detect the interaction effects of the studied SNPs we used a non-parametric MDR approach. MDR software has selected the 2 SNPs $\left(M M P 9\left(\mathrm{C}^{-1562} \rightarrow \mathrm{T}\right)\right.$ and $N O S 37$ exon $\left(\mathrm{Glu}_{298} \rightarrow \mathrm{Asp}\right)$ for the best model with the highest predictive potential (with testing accuracy of $74.6 \%$, cross-validation consistency 9 of 10 and $\mathrm{P}<0,05)$. MDR software

Table 5. Results of logistic regression with 2 SNPs in the model.

\begin{tabular}{|c|c|c|c|c|c|c|c|}
\hline SNP & $\begin{array}{l}\text { Geno- } \\
\text { type }\end{array}$ & $\begin{array}{c}\text { Coefficient } \\
\text { of regres- } \\
\text { sion }\end{array}$ & $\begin{array}{c}\text { Wald } \\
\text { statistics }\end{array}$ & $\begin{array}{c}\mathrm{P} \\
\text {-value }\end{array}$ & OR & $\begin{array}{l}95 \% \mathrm{CI} \\
\text { for OR } \\
\text { lower }\end{array}$ & $\begin{array}{l}95 \% \mathrm{CI} \\
\text { for OR } \\
\text { upper }\end{array}$ \\
\hline \multirow{2}{*}{$\begin{array}{l}\text { MMP9 } \\
\left(\mathrm{C}^{-1562} \rightarrow \mathrm{T}\right)\end{array}$} & $C / T$ & 2,109 & 13,282 &, 000 & 8,24 & 2,65 & 25,63 \\
\hline & $T / T$ & 21,648 & $6,5 \times 10^{-7}$ & ,999 & $2,5 \times 10^{9}$ & & \\
\hline \multirow{2}{*}{$\begin{array}{l}\text { NOS3 } 7 \text { exon } \\
\left(\mathrm{Glu}_{298} \rightarrow \mathrm{Asp}\right)\end{array}$} & Glu/Asp & $-1,760$ & 7,747 & ,005 &, 17 &, 05 & ,59 \\
\hline & $A s p / A s p$ & $-1,450$ & 1,480 & ,224 &, 24 &, 02 & 2,42 \\
\hline \multicolumn{2}{|c|}{ Constant } &, 666 & 1,493 &, 222 & 1,95 & & \\
\hline
\end{tabular}

OR - odds ratio, $\mathrm{CI}$ - confidential interval

indicated that MMP9 $\left(\mathrm{C}^{-1562} \rightarrow \mathrm{T}\right)$ and NOS3 7 exon $\left(\mathrm{Glu}_{298} \rightarrow \mathrm{Asp}\right)$ have very weak interaction effect and represent 2 main effects as suggested by logistic regression (figure 2).

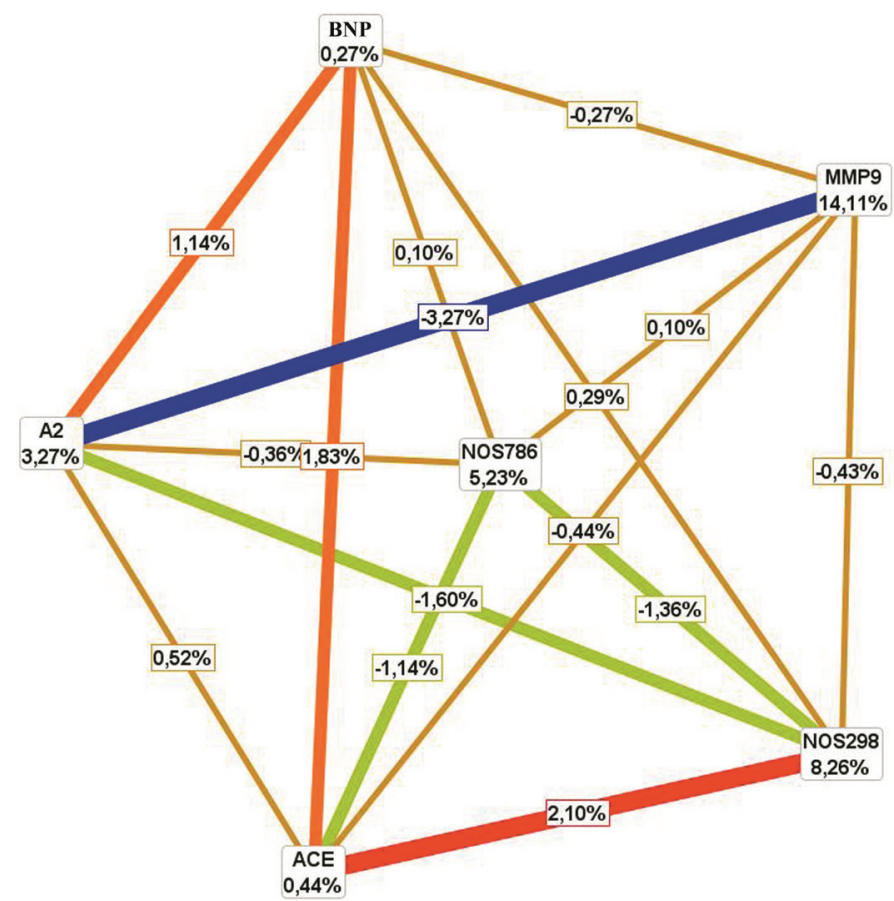

Fig. 2. SNPs interaction graph-model. This interaction model describe the percent of the entropy that is explained by each factor. Each SNP is shown in a box with the percent of entropy below the label. A2 - A2M (Ile ${ }_{1000} \rightarrow$ Val), BNP - NPPB (T ${ }^{-381} \rightarrow$ C), MMP9 - MMP9 $\left(\mathrm{C}^{-1562} \rightarrow \mathrm{T}\right), \mathrm{NOS} 298-\operatorname{NOS} 3\left(\mathrm{Glu}_{298} \rightarrow \mathrm{Asp}\right), \mathrm{NOS} 786-N O S 3\left(\mathrm{~T}^{-786} \rightarrow \mathrm{C}\right), \mathrm{ACE}-A C E(\mathrm{I} / \mathrm{D})$. Interactions between SNPs are depicted as lines in different intencity of gray color. Synergy is depicted as a dark gray line between SNPs accompanied by a positive percent of entropy while redundancy is indicated as a light gray line accompanied by a negative percent of entropy 


\section{DISCUSSION}

The main goal of the present study was to create the predictive model for evaluation of predisposition to essential arterial hypertension $(\mathrm{EH})$ in children. We have analyzed 14 SNPs in pathophysiologically meaning genes and created the model of two predictors: NOS3 $\left(\mathrm{Glu}_{298} \rightarrow \mathrm{Asp}\right)$ and $M M P 9\left(\mathrm{C}^{-1562} \rightarrow \mathrm{T}\right)$.

Interpretation of the role of SNPs in pathogenesis of EH seems to be easy when it concerns genes, directly involved in regulation of blood pressure. For example, we speculate that carriers of rare genotypes by SNPs in gene NOS3 are more predisposed to EH. Because they are characterized by lower level and/or catalytic activity of eNOS, and correspondingly NO, that leads to impaired vasodilatation [23, 32, 41, 49]. But in our study we have shown that rare allele of $N O S 3\left(\mathrm{Glu}_{298} \rightarrow \mathrm{Asp}\right)$ is protective against $\mathrm{EH}$ - carriers of Glu/Asp genotype has 6.3-fold lower risk of EH comparing with carriers of Glu/ Glu genotype. Furthermore, the functional role of this SNP is not clear that additionally tangles the interpretation of obtained results.

The most powerful influence on risk of $\mathrm{EH}$ in children we have found for $M M P 9\left(\mathrm{C}^{-1562} \rightarrow \mathrm{T}\right)$ - $\mathrm{C} / \mathrm{T}$ genotype carriers are 8.6-fold predisposed to $\mathrm{EH}$ than $\mathrm{C} / \mathrm{C}$ carriers. We did not include $\mathrm{C} / \mathrm{C}$ genotype by $M M P 9\left(\mathrm{C}^{-1562} \rightarrow \mathrm{T}\right)$ into our model because of its absence in group of controls, however, its appearance in hypertensives is approximately $4,0 \%$. It let us to consider the persons with this genotype at higher risk of $\mathrm{EH}$.

Functional studies of MMP9 $\left(\mathrm{C}^{-1562} \rightarrow \mathrm{T}\right)$ have estimated that each T-allele is associated with enhanced gene transcription, and as a result increased level and activity of $M M P 9$. Information concerning the role of SNPs in genes of matrix metalloproteinases, including $M M P$ 9, was obtained in studies on atherosclerosis and coronary heart disease $[1,54]$. Relationship between atherosclerosis and hypertension in adults is not a surprise but in our case we can see significant differences of alleles distribution in hypertensive vs. controls among children, while they do not have prominent atherosclerotic lesions but only endothelial dysfunction can be observed.

Different studies have shown both increased [47] and decreased [56] level of active MMP9 in hypertensives' plasma compared to controls. However, the role of this SNP has been shown to be a risk factor of atherosclerosis and coronary heart disease $[1,54]$, but the data for $\mathrm{EH}$ are absent. Recent data show the meaning of MMPs in atherosclerosis as well as in high blood pressure-related vascular remodelling $[35,53]$. Furthermore, O. Dumont et al. have shown that NO is necessary for $M M P 9$-mediated vascular remodelling that can shad the light on enigma of protective effect of NOS3 $\left(\mathrm{Glu}_{298} \rightarrow \mathrm{Asp}\right)$ SNP against EH. Hence, it is not possible to make the final conclusion about the mechanism of MMP 9 SNP realization in pathogenesis of $\mathrm{EH}$ in children.

The role of SNP in $N P P B$ is even harder to explain because the rare allele is characterized by higher level of BNP in blood, while comparing with major allele carriers, by $25 \%$ for each minor allele [24]. Taking into account the predominance of opinion about vasodilator and protective role of natriuretic peptides [33], our results about the predominance of minor allele in patients with $\mathrm{EH}$ seem to be illogical. However, for the recent time the information about competitive relations between systems of natriuretic peptides and NO-dependent pathway has appeared [28], furthermore, the congenital and permanent increase of BNP level can lead to desensitization of its receptors.

We have obtained absolutely new data on the role of SNPs in genes encoding proteasome subunits in predisposition to EH [14]. Preexisting insight rated SNPs in LMP2 only as markers of autoimmune pathology but our data directly denote the association of minor allele with risk of $\mathrm{EH}$. The most prominent differences concern the rate of heterozygous carriers among EH vs. controls. This fact seems to be more interesting if to take into account our previous investigations concerning functional meaning of LMP2 ( Arg $_{60} \rightarrow$ His) [8]. Our results show that the highest proteasomal activity is inhered to 
monocytes isolated from blood of heterozygous carriers $L M P 2_{60} \mathrm{Arg} / \mathrm{His}$, and the lowest - from homozygous carriers of minor allele $L M P 2_{60}$ His/His. The functional study of PSMA6 $\mathrm{C}^{-8} \rightarrow \mathrm{G}$ demonstrated that the transcription activity of this gene is much higher in carrires of minor allele [36]. It is noticeable that $\alpha 6$-subunit is constitutive and essential component of proteasome and furthermore, for immunoproteasome, which can both generate immunogenic peptides and destroy endogenic proteins [13].

Ubiquitous meaning of proteasomal proteolysis in nearly all intracellular pathways makes the analysis of its role and polymorphisms in genes of its subunits in regulation of vascular tone very intricate. One of the fundamental regulators of vascular tone is endothelial NOS which according to our data is also degraded via proteasomal proteolysis. So, the expected higher activity of proteasome in patients with EH hypothetically can facilitate the degradation of eNOS and lead to reduction of the strongest vasodilator - NO. But the situation is more complex because inhibitors of eNOS has much higher compliance to proteasomal proteolysis than eNOS itself [9]. Furthermore, the low doses of proteasome inhibitors activate NOS3 transcription and activity of eNOS in cultured endothelial cells [45]. For the recent years it has been shown that proteasome destroy the molecules of stromal interaction that are the fundamental factors of realization of bradykinin-dependent outflux of calcium from endoplasmic reticulum activating eNOS as calcium-dependent enzyme [57]. Physiological antagonist of bradikinin - angiotensin II influence the regulation of calcium ions outflux from endoplasmic reticulum via stimulating the proteasome-dependent degradation of inositol-3-phosphate receptor [3]. Another mechanism of angiotensin II action on vascular wall is concerned with stabilization of hypoxia inducible factor (HIF) that is degraded by proteasome under the normal conditions. It turned out to be that angiotensin II can prevent the degradation of HIF by proteasome [37], and this transcriptional factor is considered to stimulate the expression of "antihypertensive" genes because its knockdown was shown to cause the experimental hypertension onset [25]. Thus, increased activity of proteasome due to genetic variability may facilitate the high blood pressure.

Analysis of the role of single-SNP-based analysis in $\mathrm{EH}$ pathogenesis by our opinion is not informative enough because of multigenic character of this pathology. Only complex evaluation of different variable genes can give the answer about the endogenous predisposition for disease, which in combination with environmental factors.

Analysis of the role of single-SNP-based analysis in $\mathrm{EH}$ pathogenesis by our opinion is not informative because of polygenic character of this pathology. For example, the consideration of Welcome Trust genome-wide association study of essential hypertension of only one SNP as predisposing to $\mathrm{EH}$ cannot be conclusive. Furthermore, this SNP (rs 1937506) is located in locus predicted as olfactory receptor and the protocadherin 9 isoform 1 precursor genes [10]. Their role in regulation of blood pressure has not physiologically substantiated [22]. At the same time the SNPs in genes involved in pathogenesis of arterial hypertension are not shown as significant in GWAS. Furthermore, only one GWAS is dedicated to the problem of arterial hypertension in adolescent and its results differ from that in adults [32, 16, 17, 52]. In our opinion, these data indicate that genetic risk factors $\mathrm{EH}$ in children differ from those in adults. This problem should notice attention due to specificity of early onset of hypertension. Only complex evaluation of different variable genes can give the answer about the endogenous predisposition for disease.

In conclusion, the integral statistical analysis of our results gave us the possibility to create the predictive model including 2 SNPs: $M M P 9$ $\left(\mathrm{C}^{-1562} \rightarrow \mathrm{T}\right)$ and $N O S 37$ exon $\left(\mathrm{Glu}_{298} \rightarrow \mathrm{Asp}\right)$ which represent 2 main independent effects with the highest predictive potential $(77,1 \%$ as indicated by binary logistic regression and 74,6\% testing accuracy shown by MDR) which requires further validation and comparison with similar results of other research teams, and additional 
clinical data should be included on the next steps of researches aimed to create predictive algorithm for determination of predisposition to arterial hypertension in children.

\author{
С.В. Гончаров, В.Л. Гур'янова, Д.О. Строй, \\ Т.І. Древицька, С.П. Каплінський, \\ Е.А. Настенко, М. Литвиненко, \\ Р.В. Терлецький, М.В. Хайтович, \\ О.О. Мойбенко, В.С. Досенко
}

\section{ГЕНЕТИЧНА СХИЛЬНІСТЬ ДО ПЕРВИН- НОЇ АРТЕРІАЛЬНОЇ ГІПЕРТЕНЗІЇ У ДІТЕЙ: АНАЛІЗ 17 ОДНОНУКЛЕОТИДНИХ ПОЛІМОРФІЗМІВ}

У 145 дітей з артеріальною гіпертензією та 144 відносно здорових осіб за допомогою полімеразної ланцюгової реакції (ПЛР) з наступним аналізом рестриктованих фрагментів було визначено такі поліморфізми: NOS3 $\left(\mathrm{T}^{-786} \rightarrow \mathrm{C}\right)$ та NOS3 $\left(\mathrm{Glu}_{298} \rightarrow \mathrm{Asp}\right), A G T\left(\mathrm{Met}_{235} \rightarrow \mathrm{Thr}\right)$ та $A G T R 1\left(\mathrm{~A}^{1166} \rightarrow \mathrm{C}\right), N P P B\left(\mathrm{~T}^{-381} \rightarrow \mathrm{C}\right), A 2 M \mathrm{I} / \mathrm{D}$ у екзоні 18 и $A 2 M\left(\mathrm{Ile}_{1000} \rightarrow \mathrm{Val}\right), M M P 9\left(\mathrm{C}^{-1562} \rightarrow \mathrm{T}\right), L M P 2\left(\mathrm{Arg}_{60} \rightarrow \mathrm{His}\right) \mathrm{\text {та }}$ $L M P 7\left(\right.$ Lys $\left._{49} \rightarrow \mathrm{Gln}\right), 12$-му екзоні HIFl $\alpha\left(\mathrm{C}^{1744} \rightarrow \mathrm{T}\right), P P A R G$ $\left(\mathrm{Pro}_{12} \rightarrow \mathrm{Ala}\right), \mathrm{XRCC1}\left(\mathrm{Arg}_{399} \rightarrow \mathrm{Gln}\right)$, за допомогою ПЛР - інсерційно-делеційні поліморфізми 4-го інтрону гена NOS3 та 16-го інтрону гена ACE; алель-специфічної ПЛР - MMP2 $\left(\mathrm{C}^{-1306} \rightarrow \mathrm{T}\right)$, та ПЛР у реальному часі - PSMA6 $\left(\mathrm{C}^{-8} \rightarrow \mathrm{G}\right)$. Інтегральний статистичний аналіз отриманих результатів дав змогу створити предиктивну модель, що включає два однонуклеотидні поліморфізми: $M M P 9$ $\left(\mathrm{C}^{-1562} \rightarrow \mathrm{T}\right)$ та $N O S 3\left(\mathrm{Glu}_{298} \rightarrow \mathrm{Asp}\right)$, що являють собою 2 головні незалежні ефекти 3 найбільшою предиктивною силою $(77,1 \%$ за результатами бінарної логістичної регресії та 74,6\% за результатами методу багатофакторного зменшення розмірності).

Ключові слова: однонуклеотидний поліморфізм, генетика, гіпертензія.

Ін-т фізіології ім. О.О. Богомольия НАН України, Київ;

Наи. мед. ун-т ім. О.О. Богомольия, Київ

С.В. Гончаров, В.Л. Гурьянова, Д.А. Строй, Т.И. Древицкая, С.П. Каплинский, Е.А. Настенко, М. Литвиненко, Р.В. Терлецкий, М.В. Хайтович, А.А. Мойбенко, В.Е. Досенко

ГЕНЕТИЧЕСКАЯ ПРЕДРАСПОЛОЖЕННОСТЬ К ПЕРВИЧНОЙ АРТЕРИАЛЬНОЙ ГИПЕРТЕНЗИИ У ДЕТЕЙ: АНАЛИЗ 17 ОДНОНУКЛЕОТИДНЫХ ПОЛИМОРФИЗМОВ

У 145 детей с артериальной гипертензией и 144 относительно здоровых детей с помощью полимеразной цепной реакции (ПЦР) с последующим анализом рестрикционных фрагментов были определены следующие однонуклеотидные полиморфизмы: NOS3 $\left(\mathrm{T}^{-786} \rightarrow \mathrm{C}\right)$ и $N O S 3\left(\mathrm{Glu}_{298} \rightarrow \mathrm{Asp}\right), A G T\left(\mathrm{Met}_{235} \rightarrow \mathrm{Thr}\right)$ и $A G T R 1$ $\left(\mathrm{A}^{1166} \rightarrow \mathrm{C}\right), N P P B\left(\mathrm{~T}^{-381} \rightarrow \mathrm{C}\right), A 2 M \mathrm{I} / \mathrm{D}$ в экзоне 18 и $A 2 M$ $\left(\mathrm{Ile}_{1000} \rightarrow \mathrm{Val}\right), M M P 9\left(\mathrm{C}^{-1562} \rightarrow \mathrm{T}\right), L M P 2\left(\mathrm{Arg}_{60} \rightarrow \mathrm{His}\right)$ и $L M P 7\left(\right.$ Lys $\left._{49} \rightarrow \mathrm{Gln}\right), 12$-м экзоне $\mathrm{HIF} 1 \rightarrow\left(\mathrm{C}^{1744} \rightarrow \mathrm{T}\right)$, PPARG $\left(\mathrm{Pro}_{12} \rightarrow \mathrm{Ala}\right), X R C C 1$ ( $\left.\operatorname{Arg}_{399} \rightarrow \mathrm{Gln}\right)$, с помощью ПЦР - инсерционно-делеционные полиморфизмы в 4-ом интроне гена $N O S 3$ и 16-м интроне гена $A C E$; аллель-специфической ПЦР $-M M P 2\left(\mathrm{C}^{-1306} \rightarrow \mathrm{T}\right)$, и ПЦР у реальном времени $-P S M A 6\left(\mathrm{C}^{-8} \rightarrow \mathrm{G}\right)$. Интегральный статистический анализ полученных результатов позволил создать предиктивную модель, включающую 2 однонуклеотидных полиморфизма: $M M P 9\left(\mathrm{C}^{-1562} \rightarrow \mathrm{T}\right)$ и $N O S 3\left(\mathrm{Glu}_{298} \rightarrow \mathrm{Asp}\right)$, представляющие 2 главные независимые эффекты с наибольшей предиктивной силой $(77,1 \%$ по результатам бинарной логистической регрессии и $74,6 \%$ по результатам метода многофакторного уменьшения размерности).

Ключевые слова: однонуклеотидный полиморфизм, генетика, гипертензия.

\section{REFERENCES}

1. Abilleira S., Bevan S., Markus H.S. The role of genetic variants of matrix metalloproteinases in coronary and carotid atherosclerosis // J. Med. Genet. - 2006. - 43. - P.897-901.

2. Al-Shali K.Z., House A.A., Hanley A.J., Khan H.M., Harris S.B., Zinman B., Mamakeesick M., Fenster A., Spence J.D., Hegele R.A. Genetic variation in PPARG encoding peroxisome proliferator-activated receptor gamma associated with carotid atherosclerosis // Stroke. - 2004. - 35. - P.2036-2040.

3. Bokkala S., Joseph S.K. Angiotensin II-induced downregulation of inositol trisphosphate receptors in WB rat liver epithelial cells. Evidence for involvement of the proteasome pathway // J. Biol. Chem. -1997. - 272. P.12454-12461.

4. Buraczyńska M., Grzebalska A., Spasiewicz D., Orłowska G., Ksiazek A. Genetic polymorphisms of renin-angiotensin system and progression of interstitial nephritis // Ann. Univ. Mariae Curie Sklodowska Med. - 2002. - 57. - P.330-336.

5. Conen D., Cheng S., Steiner L.L., Buring J.E., Ridker P.M., Zee R.Y. Association of 77 polymorphisms in 52 candidate genes with blood pressure progression and incident hypertension: the Women's Genome Health Study // J. Hypertens. - 2009. - 27. - P.476-483.

6. Dodel R.C., Bales K.R., Farlow M.R., Gasser T., Paul S.M., Du Y. Rapid detection of a pentanucleotide deletion polymorphism in the human alpha2-macroglobulin gene // Clin. Chem. - 1999. - 45. - P.307-317.

7. Doris P.A. Hypertension genetics, single nucleotide polymorphisms, and the common disease: common variant hypothesis // Hypertension. - 2002. - 39. - P.323-331.

8. Dosenko V.E., Mykhal'chuk D.V., Zahoriǔ V.Iu., 
Khă̈tovych M.V., Moĭbenko O.O. Allelic polymorphism of genes encoding catalytic immunoproteasome subunits and its functional meaning // Fiziol. Zh. -2005 . - 51. P.3-10.

9. Dosenko V.E., Zagoriǐ V.Iu., Moǐbenko A.A. Effect of proteasomal proteolysis on NO-synthase activity in isolated platelets // Ukr. Biokhim. Zh. - 2005. - 77. - P.39-43.

10. Ehret G.B., Morrison A.C., O'Connor A.A., Grove M.L., Baird L., Schwander K., Weder A., Cooper R.S., Rao D.C., Hunt S.C., Boerwinkle E., Chakravarti A. Replication of the Welcome Trust genome-wide association study of essential hypertension: The Family Blood Pressure Program // Eur. J. Hum. Genet. - 2008. - 16. - P.1507-1511.

11. Evans A.E., Poirier O., Kee F., Lecerf L., McCrum E., Falconer T., Crane J., O'Rourke D.F., Cambien F. Polymorphisms of the angiotensin-converting-enzyme gene in subjects who die from coronary heart disease // Q. J. Med. - 1994. - 87. - P.211-214.

12. Ghilardi G., Biondi M.L., DeMonti M., Bernini M., Turri O., Massaro F., Guagnellini E., Scorza R. Independent risk factor for moderate to severe internal carotid artery stenosis: T786C mutation of endothelial nitric oxide synthase gene // Clin. Chem. - 2002. - 48. - P.989-993.

13. Goldberg A.L. Protein degradation and protection against misfolded or damaged proteins // Nature. - 2003. - 426. - P.895-899.

14. Goncharov S.V., Dosenko V.Ie., Khă̌tovych M.V., Moỉbenko O.O. Allele polymorphism of genes coding proteasome subunits is associated with an enhanced risk for arterial hypertension in adolescents // Fiziol. Zh. 2009. - 55. - P.3-10.

15. Hibi K., Ishigami T., Tamura K., Mizushima S., Nyui N., Fujita T., Ochiai H., Kosuge M., Watanabe Y., Yoshii Y., Kihara M., Kimura K., Ishii M., Umemura S. Endothelial nitric oxide synthase gene polymorphism and acute myocardial infarction // Hypertension. - 1998. - 32. P. 521-526.

16. Hiura Y., Tabara Y., Kokubo Y., Okamura T., Miki T., Tomoike H., Iwai N. A genome-wide association study of hypertension-related phenotypes in a Japanese population // Circ. J. - 2010. - 74(11). - P.2353-2359.

17. Johnson T., Gaunt T.R., Newhouse S.J. Blood pressure loci identified with a gene-centric array // Amer. J. Hum. Genet. - 2011. - 89(6). - P.688-700.

18. Jones G.T., Phillips V.L., Harris E.L., Rossaak J.I., van Rij A.M. Functional matrix metalloproteinase-9 polymorphism (C-1562T) associated with abdominal aortic aneurysm // J. Vasc. Surg. - 2003. - 38. - P.13631367.

19. Kato N. Genetic analysis in human hypertension // Hypertens. Res. -2002 . - 25. - P.319-27.

20. Kupper N., Ge D., Treiber F.A., Snieder H. Emergence of novel genetic effects on blood pressure and hemodynamics in adolescence: the Georgia Cardiovascular Twin Study // Hypertension. - 2006. - 47. - P.948-954. 21. Kurland L., Liljedahl U., Lind L. Hypertension and SNP genotyping in antihypertensive treatment // Cardiovasc. Toxicol. - 2005. - 5. - P.133-142.

22. Kurtz T.W. Genome - wide association studies will unlock the genetic basis of hypertension: con side of the argument // Hypertension. - 2010. - 56. - P.1021-1025.

23. Lacolley P., Gautier S., Poirier O., Pannier B., Cambien F., Benetos A. Nitric oxide synthase gene polymorphisms, blood pressure and aortic stiffness in normotensive and hypertensive subjects // J. Hypertens. - 1998. - 16. P.31-35.

24. Lanfear D.E., Stolker J.M., Marsh S., Rich M.W., McLeod H.L. Genetic variation in the B-type natiuretic peptide pathway affects BNP levels // Drugs. Ther. -2007. - 21. - P.55-62.

25. Li N., Chen L., Yi F., Xia M., Li P.L. Salt-sensitive hypertension induced by decoy of transcription factor hypoxia-inducible factor-1alpha in the renal medulla // Circ. Res. - 2008. - 102. - P.1101-1108.

26. Lunn R.M., Langlois R.G., Hsieh L.L., Thompson C.L., Bell D.A. XRCC1 polymorphisms: effects on aflatoxin B1-DNA adducts and glycophorin A variant frequency // Cancer. Res. - 1999. - 59. - P.2557-2561.

27. Lurbe E., Cifkova R., Cruickshank J.K., Dillon M.J., Ferreira I., Invitti C., Kuznetsova T., Laurent S., Mancia G., Morales-Olivas F., Rascher W., Redon J., Schaefer F., Seeman T., Stergiou G., Wühl E., Zanchetti A.; European Society of Hypertension. Management of high blood pressure in children and adolescents: recommendations of the European Society of Hypertension // J. Hypertens. - 2009. - 27. - P.1719-1742.

28. Madhani M., Okorie M., Hobbs A.J., MacAllister R.J. Reciprocal regulation of human soluble and particulate guanylate cyclases in vivo // Brit. J. Pharmacol. - 2006. - 149. - P.797-801.

29. Maydannik V.G., Moskalenko V.F. Primary arterial hypertension in children and adolescents. - Kiev, 2007 P. 5-45.

30. Meirhaeghe A., Sandhu M.S., McCarthy M.I., de Groote P., Cottel D., Arveiler D., Ferrières J., Groves C.J., Hattersley A.T., Hitman G.A., Walker M., Wareham N.J., Amouyel P. Association between the T-381C polymorphism of the brain natriuretic peptide gene and risk of type 2 diabetes in human populations // Hum. Mol. Genet. - 2007. - 16. - P.1343-1350.

31. Melka M.G., Bernard M., Mahboubi A., Abrahamowicz M., Paterson A.D., Syme C., Lourdusamy A., Schumann G., Leonard G.T., Perron M., Richer L., Veillette S., Gaudet D., Paus T., Pausova Z. // J. Clin. Endocrinol. Metab. - 2012. - 97(1). - P.145-50.

32. Miyamoto Y., Saito Y., Kajiyama N., Yoshimura M., Shimasaki Y., Nakayama M., Kamitani S., Harada M., Ishikawa M., Kuwahara K., Ogawa E., Hamanaka I., Takahashi N., Kaneshige T., Teraoka H., Akamizu T., Azuma N., Yoshimasa Y., Yoshimasa T., Itoh H., Masuda I., Yasue H., Nakao K. Endothelial nitric oxide synthase gene is positively associated with essential hypertension // Hypertension. - 1998. - 32. - P.3-8. 
33. Nishikimi T., Maeda N., Matsuoka H. The role of natriuretic peptides in cardioprotection // Cardiovasc. Res. 2006. - 69. - P.318-328.

34. O-charoenrat P., Khantapura P. The role of genetic polymorphisms in the promoters of the matrix metalloproteinase- 2 and tissue inhibitor of metalloproteinase- 2 genes in head and neck cancer // Oral Oncol. - 2006. - 42. - P.257-267.

35. Dumont O., Loufrani L., Henrion D. Key Role of the NO-Pathway and Matrix Metalloprotease-9 in High Blood Flow-Induced Remodeling of Rat Resistance Arteries // Arterioscler. Thromb. Vasc. Biol. - 2007. 27. - P.317-324.

36. Ozaki K., Sato H., Iida A. A functional SNP in PSMA6 confers risk of myocardial infarction in the Japanese population // Nat. Genet. - 2006. - 38. - P.921-925.

37. Pagé E.L., Chan D.A., Giaccia A.J., Levine M., Richard D.E. Hypoxia-inducible factor-1 \{alpha\} stabilization in nonhypoxic conditions: role of oxidation and intracellular ascorbate depletion // Mol. Biol. Cell. -2008. - 19. - P.86-94.

38. Percy M.J., Mooney S.M., McMullin M.F., Flores A., Lappin T.R., Lee F.S. A common polymorphism in the oxygen-dependent degradation (ODD) domain of hypoxia inducible factor-1alpha (HIF-1alpha) does not impair Pro-564 hydroxylation // Mol. Cancer-2003. - 2. - P.31.

39. Petrovic D., Bidovec M., Peterlin B. Gene polymorphisms of the renin-angiotensin-aldosterone system and essential arterial hypertension in childhood // Folia Biol. - 2002. - 50. - P.53-56.

40. Shastry B.S. SNPs: impact on gene function and phenotype // Methods Mol. Biol. - 2009. - 578. - P.3-22.

41. Shoji M., Yasujima M. Endothelial nitric oxide synthase gene and hypertension // Nippon. Rinsho - 2000. - 58. - P.570-573.

42. Snieder H., Dong Y., Barbeau P., Harshfield G.A., Dalageogou C., Zhu H., Carter N.D., Treiber F.A. Beta2adrenergic receptor gene and resting hemodynamics in European and African American youth // Amer. J. Hypertens. - 2002. - 15. - P.973-979.

43. Snieder H., Harshfield G.A., Treiber F.A. Heritability of blood pressure and hemodynamics in African- and European-American youth // Hypertension. - 2003. 41. - P.1196-1201.

44. Staessen J.A., Asmar R., De Buyzere M., Imai Y., Parati G., Shimada K., Stergiou G., Redón J., Verdecchia P.; Participants of the 2001 Consensus Conference on Ambulatory Blood Pressure Monitoring. Task Force II: blood pressure measurement and cardiovascular outcome // Blood Press Monit. - 2001 - 6 - P. 355-357.

45. Stangl V., Lorenz M., Meiners S., Ludwig A., Bartsch C., Moobed M., Vietzke A., Kinkel H.T., Baumann G., Stangl K. Long-term up-regulation of eNOS and improvement of endothelial function by inhibition of the ubiquitin-proteasome pathway // FASEB J. - 2004. - 18. - P.272-279.

46. Strobl C., Malley J., Tutz G. An Introduction to recursive partitioning: rationale, application and characteristics of classification and regression trees, bagging and random forests // Psychol. Methods. -2009. - 14(4). - P.323-348.

47. Su W., Gao F., Lu J., Wu W., Zhou G., Lu S. Levels of Matrix Metalloproteinase-9 and Tissue Inhibitor of Metalloproteinase-1 mRNAs in Patients with Primary Hypertension or Hypertension-induced Atherosclerosis // J. Int. Med. Res. - 2012. - 40. - P.986-994.

48. Takashima N., Shioji K., Kokubo Y., Okayama A., Goto Y., Nonogi H., Iwai N. Validation of the association between the gene encoding proteasome subunit alpha type 6 and myocardial infarction in a Japanese population // Circ. J. - 2007. - 71. - P.495-498.

49. Tsujita Y., Baba S., Yamauchi R., Mannami T., Kinoshita M., Yamamoto R., Katsuya T., Higaki J., Ogihara T., Ogata J., Iwai N. Association analyses between genetic polymorphisms of endothelial nitric oxide synthase gene and hypertension in Japanese: The Suita Study // J. Hypertens. - 2001. - 19. - P.1941-1948.

50. Vinasco J., Fraile A., Nieto A., Beraun Y., Pareja E., Mataran L., Martín J. Analysis of Lmp and Tap Polymorphisms by Polymerase Chain Reaction - Restriction Fragment Length Polymorphism in Rheumatoid Arthritis // Ann. Rheum. Dis. - 1998. - 57. - P.33-37.

51. Wang X.L., Sim A.S., Wang M.X., Murrell G.A., Trudinger B., Wang J. Genotype dependent and cigarette specific effects on endothelial nitric oxide synthase gene expression and enzyme activity // FEBS Lett. - 2000. - 471. - P.45-50.

52. Yang H.C., Liang Y.J., Wu Y.L., Chung C.M., Chiang K.M., Ho H.Y., Ting C.T., Lin T.H., Sheu S.H., Tsai W.C., Chen J.H., Leu H.B., Yin W.H., Chiu T.Y., Chen C.I., Fann C.S., Wu J.Y., Lin T.N., Lin S.J., Chen Y.T., Chen J.W., Pan W.H. Genome-wide association study of youngonset hypertension in the Han Chinese population of Taiwan // PLoS One. - 2009. - 4(5). - P.5459.

53. Yasmin, Wallace S., McEniery C.M., Dakham Z., Pusalkar P., Maki-Petaja K., Ashby M.J., Cockcroft J.R., Wilkinson I.B.. Matrix Metalloproteinase-9 (MMP-9), MMP-2, and Serum Elastase Activity Are Associated With Systolic Hypertension and Arterial Stiffness // Arterioscler. Thromb. Vasc. Biol. - 2005. - 25. - P.372-378.

54. Ye S. Influence of matrix metalloproteinase genotype on cardiovascular disease susceptibility and outcome. // Cardiovasc. Res. - 2006. - 69. - P.636-645.

55. Zappia M., Manna I., Serra P., Cittadella R., Andreoli V., La Russa A., Annesi F., Spadafora P., Romeo N., Nicoletti G., Messina D., Gambardella A., Quattrone A. Increased risk for Alzheimer disease with the interaction of MPO and A2M polymorphisms // Arch. Neurol. - 2004. - 61. - P.341-344.

56. Zervoudaki A., Economou E., Stefanadis C., Pitsavos C., Tsioufis K., Aggeli C., Vasiliadou K., Toutouza M., Toutouzas P. Plasma levels of active extracellular matrix metalloproteinases 2 and 9 in patients with essential hypertension before and after antihypertensive treatment // J. Hum. Hypertens. - 2003. - 17. - P.119-124. 
57. Zhang W., Meng H., Li Z.H., Shu Z., Ma X., Zhang B.X. Regulation of STIM1, store-operated $\mathrm{Ca}^{2+}$ influx, and nitric oxide generation by retinoic acid in rat mesangial cells // Amer. J. Physiol. Renal Physiol. - 2007. - 292. - P.1054-1064.

O.O. Bogomoletz Institute of Physiology, NAS of Ukraine, Kiev;

O.O. Bogomoletz National Medical University, Kiev

E-mail: sergei_goncharov@bigmir.net
58. Zorc-Plesković R., Bidovec M., Bregar D., Milutinović A., Terzić R., Teran N. The ScaI gene polymorphism of the atrial natriuretic factor and essential arterial hypertension in childhood // Coll. Antropol. - 2004. 28. - P.617-621. 